\title{
Otel Çalışanlarının Stres ve Bireysel Performans İlişkisinin Incelenmesi
}

\author{
Investigation of the Relationship with the Individual \\ Performance of the Stress of Hotel Employees
}

\author{
Arş.Gör. Gamze Alp ${ }^{1}$
}

Başvuru Tarihi: 11.05.2017

Kabul Tarihi: 21.05.2019

\section{Öz}

$\mathrm{Bu}$ araştırmada stres puanları ile bireysel performans arasındaki ilişkinin incelenmesi amaçlanmıştır. Bu amaca uygun olarak araştırmada ilişkisel tarama modeli kullanılmıştır. Araştırmanın örneklemini, 2016 yılının Nisan ve Mayıs aylarında Antalya merkezdeki beşyıldızlı otel çalışanları oluşturmaktadır. Araştırmada çalışanların stres puanlarını hesaplamak için "Mayerson stres kaynağı ölçeği" kullanılmıştır. Çalışanların bireysel performanslarının değerlendirilebilmesi için de "bireysel performans ölçeğì" kullanılmıştır. Araştırmada sosyal stres vericiler, kendini yorumlama biçiminden kaynaklanan stres vericiler, işle ilgili stres vericiler ve fiziki çevreden kaynaklanan stres vericiler değişkenlerinden oluşan veri setlerinden elde edilen stres puanları ile, temel performans ve başarı performansı değişkenlerinden oluşan bireysel performans ölçeği veri seti arasındaki ilişki kanonik korelasyon analizi ile incelenmiştir. Kanonik korelasyon analizi sonucunda, stres puanları ve bireysel performans arasında anlamli pozitifilişki tespit edilmiş ve sosyal stres vericilerden alınan puanlar değişkeni ile bireysel performans arasında pozitif bir ilişki bulunmuştur. Bu da, çalışanların sosyal stres vericilerden aldıkları puanlar arttıkça bireysel performanslarının da artı̆̆ını göstermektedir.

Anahtar Kelimeler: Stres Puani, Kanonik Korelasyon, Bireysel Performans

\begin{abstract}
In this research, it is aimed to examine the relationship between stress scores and individual performance evaluation. For this purpose, the relational scan model is used in the research. The working group of the research is employees working in five star hotels in the center of Antalya in April and May 2016. The "Mayerson stress source scale" was used to calculate the stress scores of the workers in the study. The "Individual performance scale" was used to evaluate the individual performance of the employees. In the study, the relationship between stress scores obtained from data sets consisting of social stressors, stressors from the way of self-interpretation, work-related stressors and stressors caused by physical environment variables and the individual performance scale data set consisting of basic performance and achievement performance variables were analyzed by canonical correlation analysis. As a result of the canonical correlation analysis, a significant positive correlation was found between stress scores and individual performance, and
\end{abstract}


a positive correlation was found between the scores of social stressors and the scores of personal performance. This shows that the personal performance of employees increases as the points they get from social stressors increase.

Keywords: Stress Score, Canonical Correlation, Individual Performance

\section{Giriş}

Stres, kişinin bireysel veya bireysel yapamayacağı bir durum arasında kalarak isteklerini karşılamak ve baskılara karşı direnmek arasındaki yaşadığı ikilemden oluşmaktadır(Canpolat, 2006, s. 12). Ulusal İş Sağllğı ve Güvenliği Enstitüsü(NIOSH) mesleki stresi, mesleki koşulların iş gücünün yeteneklerini, gereksinimlerini ve mevcut olanaklarını karşıllayamadığı zamanlarda oluşan bireyin fiziki ve duygusal tepkileri olarak tanımlamaktadır(Samartha, Lokesh ve Karkera, 2010).

Çalışılan kurumun yapısı, çalışma koşulları ve kişilerarası ilişkiler gibi iş ve organizasyonla ilgili faktörlerin yanı sıra ev ve aile sorunlarının da iş stresi üzerinde etkisi bulunmaktadır (Chiang, Birtch ve Kwan, 2010). Çalışma ortamı ve ev sorunları gibi faktörler sonucu oluşan iş stresi, iş performansını da önemli ölçüde etkilemektedir. İş kaynaklı stres, bireyin yetenek ve kapasitesini aşmadığı sürece motivasyonunu arttırarak performansını geliştirebilmektedir. Ancak iş stresi, bireyin başa çıkma kapasitesini aştığında bireysel ve örgütsel performansı üzerinde baskılayıcı bir etkiye sahip olabilmektedir. Pek çok çalı̧̧mada da iş stresi ve performans arasındaki negatif ilişki gösterilmektedir(French, Lenton, Walter ve Eyles, 2000; AbuAlrub, 2004; AbuAlRub, 2006; Chen ve Huang, 2014).

Mesleki stres düzeyinin, çalışanların iş performansını etkileyen önemli bir faktör olduğu farklı araştırmacilar tarafından da ileri sürülmüştür (Beehr, Jex, Stacy, ve Murray, 2000; Varca, 1999). Araştırmacılar, otel sektöründe iş stresinin çok sayıda nedenini belirtmektedirler:

- Maaş gecikmeleri ve meslek kategorilerinin birleştirilmesi (Bernhardt vd., 2003),

- İşin özellikleri (Chiang, Birtch ve Kwan, 2010),

- İş güvencesizliği (Gilboa, Shiram, Fried ve Cooper, 2008)

- Sınırlı iş kontrolü ve düşük karar verme yetkisi (Papadopoulou-Bayliss, Ineson ve Wilkie, 2001)

- Belirsiz iş tanımları ve düşük motivasyon (Robbins, 2001)

- Asgari ücretle uzun çalışma saatleri (Seta, Paulus ve Baron, 2000).

Öte yandan, Braham (1998) ve Kim, Shin ve Umbreit, (2007), otel çalışanlarının iş stresinin temelinde bireysel farklılıkların (öz yeterlilik, kişilik vb.) olduğunu iddia etmiştir. Yukarıda belirtilen nedenlerden dolayı ve iş faktörü nedeniyle otel çalışanlarının yaşadığı stres, işyerindeki performanslarını etkilemekte, aynı zamanda müşterilerin hizmet kalitesi algılarını (Karatepe ve Tizabi, 2011) ve müşteri memnuniyetini (Li, Sanders ve Frenkel, 2012) de etkilemektedir. Otel sektörünün emek-yoğun özelliğe sahip olduğu düşünüldüğünde endüstrinin başarısı çalışanların bireysel performanslarına bağlıdır (Walker, 2007). Bu nedenle, mesleki stres seviyesinin azaltılması otel sektöründe uygulayıcılar ve araştırmacılar için büyük önem taşımaktadır (Chiang, Birtch, ve Kwan, 2010; Kim, Murrmann, ve Lee, 2009). Mesleki strese maruz kalan otel çalı̧sanları, rollerini tam olarak yerine getiremezler. Örneğin, Varca 
(1999), mesleki stres ile kaliteli müşteri hizmetleri sunumu arasında negatif bir ilişki olduğunu ileri sürmektedir. Buna ek olarak, Beehr vd. (2000), müşteri hizmetleri alanlarındaki çalışanların zayıf bir iş performansı gösterdiğini vurgulamıştır. Dahası, bu tür servis aksaklıkları otellerin imajını olumsuz olarak etkileyebilmektedir (Yoo, Shin ve Yang, 2006). Mesleki stres otel sektöründe yaygın olarak görüldüğünden (Kim, Shin ve Umbreit, 2007; Wildes, 2007) otel çalışanları mesleki strese yoğun olarak maruz kalabilmektedir (Faulkner ve Patiar, 1997). Otel ortamının, otel çalışanlarının mesleki stresini arttırma ihtimali yüksektir. Bu nedenle, stres faktörlerini öğrenmek ve çalışanların performans kalitesini artırmak için otel sektöründe mesleki stresin belirlenmesi ve daha iyi anlaşılması gerekmektedir.

Araştırma kapsamında, stresin daha iyi anlaşılması amacıyla stres puanları ve bireysel performans arasındaki ilişkinin araştırılması hususunda kanonik korelasyon analizinden(KKA) faydalanılmıştır. Kanonik korelasyon, her biri iki veya daha fazla değişkenden oluşan iki değişken seti arasındaki ilişkiyi inceleyen çok değişkenli istatistiksel bir yöntem olarak tanımlanmaktadır (Sharma, 1996; Tabachnick ve Fidell, 2006; Kaya, 2008; Kalayc1, 2014). Yani, KKA bağımlı ve bağımsız değişkenler arasındaki ilişkileri inceleyen en genel modeldir. Kanonik korelasyon kullanılarak varılacak amaçlar ise şu şekildedir: Otel çalışanlarının stres puanları ve bireysel performansları arasındaki ilişkinin ne yönde olduğunun araştırılması ve hangi stres türünün bireysel performansla ilişkisinin daha yüksek olduğunun tespit edilmesidir.

Araştırma sonunda hangi stres puanı ve türünün bireysel performansla ilişkisinin daha iyi olduğu irdelenebileceğinden, etkili insan kaynağı yönetimi ile ilgili pratik sonuçların vurgulanması hedeflenmektedir. Çalışmanın sonuçlarını kullanan otel yöneticileri, otel sektöründeki stres etkisini daha iyi anlayacağından, etkili insan kaynağı yönetimi ile beraber pratik sonuçlara ulaşabilecektir. Bu nedenle de çalışmanın otelciler için, otel sektöründe stresin etkilerini anlamak ve optimum çalışan performansı elde etmek için yönetim stratejilerini daha iyi konuma getirmelerine yardımcı olması beklenmektedir.

\section{Literatür Taraması}

İş Stresi: Kahn ve Byosiere (1994) iş stresini çalışan ile işi arasında özel bir ilişki olarak tanımlamaktadır. Malta (2004) ise, iş stresinin bir rahatsızlık olduğunu belirtmektedir. Örgütsel stres literatüründen elde edilen bilgiler, iş stresinin 5 kaynaktan oluştuğunu göstermektedir (Thomas ve Herson, 2002). İlki, iş yükü, çalışma saatleri, karar verme yetkisi ve fiziksel çalışma ortamını kapsayan işin kendisiyle ilişkili strestir. İkincisi, rol çatışması, rol belirsizliği ve iş sorumluluğunu içeren rol temelli strestir. Üçüncüsü, yöneticiler, astlar ve iş arkadaşları da dâhil olmak üzere kişiler arası ilişkilerin değişen doğasıyla ilgili strestir. Dördüncüsü olan kariyer stresi, iş güvensizliğinin yanı sıra kariyer gelişimi ve tanıtımı için fırsat eksikliği anlamına gelmektedir. Son olarak, iş-aile arasındaki ikilemleri ve çatışmaları içeren stres faktörleri bulunmaktadır (Cleveland, O'Neill, Himelright, Harrison, Crouter ve Drago, 2007).

Kurumlar üzerindeki önemli etkisinden dolayı, iş stresi hizmet sektöründe önemli bir sorun olmuştur (Zohar, 1994). Çünkü çalışanların hizmet sunumunda yorgun ve sinirli hale gelmesine neden olabilen stres (Kim, 2008), hem yöneticiler hem de çalışanlar dahil olmak üzere, tüm çalışanların performanslarını etkilemektedir (Ross, 1995). Kronik strese sahip olan müşteri hizmetleri çalışanları özellikle kötü iş performansı sergilerken (Beehr, Jex, Stacy ve Murrray, 2000), stresin daha az olduğu ortamda çalışanların stresin daha fazla olduğu ortamdaki çalışanlara oranla daha iyi müşteri hizmetleri sağladığı ortaya konulmaktadır (Varca, 
1999). Diğer bir araştırma ise, iş stresinin işyerinde sadece gerginliği artırmakla kalmayıp aynı zamanda çalışanların işten ayrılmasından sonra devam eden fizyolojik reaksiyonlar ve işyerinde sağlık açısından olumsuz etkilere yol açabilecek uzun vadeli bir risk oluşturduğunu göstermektedir (Fox, Dwyer ve Ganster, 1993). Genel olarak, işle ilgili stresin, çalışanların iş performanslarının kalitesinin azalmasına (Gilboa, Shirom, Fried ve Cooper, 2008; Lepine, Podsakoff ve Lepine, 2005), tükenmişliğin artmasına, çalışanların öğrenme becerilerindeki azalmalara (Lepine, Lepine ve Jackson, 2004) neden olduğu görülmektedir. Hatta, bazı araştırmalara göre, işle ilgili stres, ülke ekonomisine hastalık ödemesi, verim kaybı, sağlık bakımı ve dava masrafları gibi şaşırtıcı maliyetlere mal olabilmektedir. Ancak, stres her zaman olumsuz ya da zararlı değildir ve stresin yokluğu bir eksikliktir. Stresli çalışanların sağlıksız, kötü motive olmuş ve verimsiz olma olasılıkları daha yüksekken, işletmelerin rekabetçi bir pazarda başarılı olma ihtimalleri ise daha düşüktür (Palmer, Cooper ve Thomas, 2004).

Rol Stresi: Çalışanlar için stres kaynaklarından biri olan rol stresi, işle ilgilidir (Vandenberghe, Panaccio, Bentein, Mignonac ve Roussel., 2011). Rol stresi, çalışanların rollerini nasıl algıladıkları ve gösterdikleri başarı arasındaki uyumsuzluğun bir sonucu olarak ortaya çıkabilmektedir (Lambert ve Lambert, 2001). Diğer bir ifade ile, rol beklentileri ile sergilenen başarı arasındaki tutarsızlık durumunda görülmektedir. Bu tutarsızlığın neden olduğu strese dayanma kapasitesinde görülen farklılıklar nedeniyle, bireylerin stresle başa çıkma yetenekleri değişkenlik göstermektedir. Bu değişkenlikler, çalışanın kişisel özelliklerinden veya işin kendisinden kaynaklanabilmektedir (Jung ve Yoon, 2013).

Rol çatışması, aşırı rol yüklenmesi ve rol belirsizliği rol stresinin üç ana bileşenidir (Cooper ve Marshall, 1976; Singh ve Dubey, 2011) ve literatürde çok sayıda araştırılmıştır (Brown ve Peterson, 1994; Jackson ve Schuler, 1985). Rol belirsizliği, organizasyondaki çalışanın rolünde bir belirsizlik olduğunda veya işgören ne yapacağını veya rolünü nasıl gerçekleştireceğini bilmediğinde ortaya çıkmaktadır. Rol çatışması, çalışanların aynı anda iki farklı rolü gerçekleştirmesi gerektiği veya bir rolün gerçekleştirilmesinin diğerine engel oluşturması durumunda görülmektedir. Bir rolün yerine getirilmesi zaman, enerji ya da kaynaklar nedeniyle çalışan için imkansız hale geldiğinde rol yüklenmesi artmaktadır. Tüm bu 3 unsur, rol çatışması, rol belirsizliği ve aşırı rol yüklenmesi, kurumların fonksiyonlarını etkileyen önemli değişkenlerdir. Bu olumsuz durumlar kurumda güven eksikliğine, kişilerarası ilişkilerde gerginliğe, düşük üretkenliğe ve düşük performansa neden olabilmektedir (Widmer, 1993).

Performans: Kurumların amaçlarına ulaşmak, uzmanlık yaptıkları ürün ve hizmetleri sunmak ve son olarak rekabet avantajı elde etmek için yüksek performans gösteren bireylere ihtiyaçları vardır. Performans kurum için olduğu kadar, birey içinde önemlidir. Görevlerin yerine getirilmesi ve üst düzeyde gerçekleştirilmesi, ustalık ve gurur duygularıyla memnuniyet kaynağ olabilmektedir. Çalışanlar için düşük performans ve hedeflere ulaşamama durumları, tatminsizlik ya da kişisel bir başarısızlık olarak algılanabilmektedir. Çünkü performans gelecekteki kariyer gelişimi ve işgücü piyasasındaki başarının tek şartı olmasa da önemli bir koşulu olarak görülmektedir. İstisnalar olsa da, yüksek performans gösterenler düşük performans gösterenlere oranla kurum içinde daha kolay bir şekilde terfi almaktadırlar (VanScotter, Motowidlo ve Cross, 2000).

Literatürde, performansı kavramsallaştırırken, eylem (yani davranışsal) ve sonuç yönü arasında ayrım yapılmaktadır (Campbell, 1990; Campbell, McCloy, Oppler ve Sager, 1993; Kanfer, 1990; Roe, 1999). Performansın davranış yönü, bir araba motorunun parçalarının monte edilmesi gibi 
bireyin işte yaptığı davranışları kapsamaktadır. Ancak her davranış performans kavramı altında ele alınmamakta, yalnızca örgütsel hedeflerle ilgili olan davranışlar performans içinde değerlendirilmektedir (Campbell vd., 1993). Dolayısıyla performans, davranışın kendisi tarafından değil, değerlendirici süreçlerle tanımlanmaktadır (Motowidlo, Borman ve Schmit, 1997). Ayrıca yalnızca ölçülebilen davranışların performans oluşturduğu düşünülmektedir (Campbell vd., 1993). Performansın sonuç yönü ise, bireyin davranışının önemini veya sonucunu ifade etmektedir. Önceki cümlelerde ifade edilen motorun parçalarının monte edilmesi davranışı, performansın sonuç yönü açısından satış rakamları gibi neticelere yol açabilmektedir. Çoğu durumda davranış ve sonuç yönleri ilişkilidir.

\section{Yöntem}

Evren olarak belirlenen Antalya merkezdeki otel çalışanlarının stres puanlarının bireysel performansla ilişkinin incelenmesi amacıyla, bağımlı ve bağımsız değişkenlerin iki veya daha fazla değişkenden oluştuğu ve bu değişkenler arasındaki ilişkiyi inceleyen, çok değişkenli istatistiksel bir yöntem olan Kanonik Korelasyon analizi kullanılması tercih edilmiştir.

\section{Araştırma Deseni}

Araştırmanın amaçları ve ulaşacağı sonuçlar göz önünde bulundurularak çalışma kapsamında ilişkisel tarama modeli kullanılmıştır. İliş̧kisel (korelatif) araştırmalar, iki ve daha fazla değişken seti arasındaki ilişkinin varlığının belirlenmesini amaçlayan araştırma desenleridir (Karasar, 2009; Erkuş, 2011).

\section{Çalışma Grubu}

Araştırmanın örneklemini, 2016 yılı 15 Nisan - 15 Mayıs tarihleri arasında Antalya merkezdeki beş yıldızlı otellerdeki 351 otel çalışanı oluşturmaktadır. Evrendeki otel çalışanlarının sayısı net olarak bilinemediğinden anketlerin örneklem büyüklüğü için yeterli olup olmadığını anlamak konusunda Tabachnick ve Fidell'in yöntemi kullanılmıştır. Tabachnick ve Fidell'e (2001) göre örneklem büyüklügünün araştırmada kullanılan değişkenlerin(Mayerson stres kaynağ ölçeğine ait 43 madde ve bireysel performans ölçeğine ait 9 madde ) an az beş katı olmasının gerekli olduğudur. Buna göre stres ve performans ölçeklerine ait 52 değişkene göre örneklem sayısının en az 260 olması gerekmektedir. Anket talebine olumlu yanıt veren 6 otelde çalışanlar basit tesadüfi örnekleme yöntemine göre seçilerek gönüllülük esasıyla anketleri doldurtulması sağlanmıştır. Tabachnick ve Fidell'e (2001)'in örneklem hesaplama yöntemine göre de 351 örneklem araştırmanın güvenilirliği için yeterli kabul edilmektedir.

\section{Veri Toplama Araçları}

Araştırmada veri toplama aracı olarak Mayerson stres kaynağı ölçeği ve bireysel performans ölçeği kullanılmıştır.

Mayerson Stres Kaynağı Ölçeği: Ölçeğin orijinal adı "Mayerson stres kaynağı ölçeği” olmasının yanında orijinal haline ulaşılamamıştır. Ölçek ilk olarak Baltaş ve Baltaş (1993, s. 173-175) tarafından Türkçeye çevrilerek kullanılmış ve araştırma kapsamında kullanılan ölçek bu çalışmadan alınmıştır. 5'li likert tipi(1-asla, 2-seyrek olarak, 3-bazen, 4-sık sık, 5-her zaman) bir derecelendirmeye sahip olan ölçekte toplam 43 ifade ve dört boyut bulunmaktadır. Çalışma kapsamında da ifadelerin hepsi kullanılmış boyutlar orjinali ile örtüşme göstermiştir. İfade puanlarının boyutlara göre toplanması sonucunda sosyal stres vericilerden alınabilecek en 
yüksek puan 85 , işle ilgili stres vericilerden 80 , kendini yorumlama biçiminden 50 , fiziki çevreden kaynaklanandan ise 25 'tir. Haşit ve Yaşar'ın (2015) çalışmasına göre, sosyal stres vericilerle (SSV); insan ilişkilerinden kaynaklanan sıkıntılarının neler olabileceği, işle ilgili stres vericilerle (İSV); iş yaşamında hangi unsurların strese yol açacağı, kendini yorumlama biçiminden kaynaklanan stres vericilerle (KYSV); bireyin kendini ve yaşadıklarını yorumlaması ile ilgili stres vericiler ve fiziki çevreden kaynaklanan stres vericiler (FSV) ile de gürültü, hava durumu gibi fiziki çevre stres unsurları belirlenmeye çalışılmıştır.

Bireysel Performans Ölçeği: Bu ölçek kapsamında çalsşanlardan 9 maddelik ve 5’li likert tipi (1kesinlikle katılmiyorum, 5-kesinlikle katıliyorum) derecelendirmelere göre bireysel performanslarını değerlendirmeleri istenmiştir. Ölçek Viswesvaran'nın (1993, s. 102) performans değerlemesinde kullandığ 1 ölçekten esinlenerek Schepers $(2005$, s. 10) tarafindan çalışanların kendi performanslarını farklı yönleriyle değerlendirmesi amacıyla oluşturulmuştur. Ölçek çalışanların kendi kendini değerlendirdiği, işin yapım sürecinde gösterdiği tempoyu, iş boyunca ortaya koyduğu performans ve görev anlayışını ölçen, işin zamanlamasındaki başarısını ölçen önermelerden oluşmaktadır.

\section{Verilerin Analizi}

Otel sektörü çalışanlarında strese neden olan faktörlerden elde edilen stres puanları ve bireysel performansları arasındaki ilişki kanonik korelasyon (KKA) analizi ile incelenmiştir. Karmaşık bir ilişki analizi olan KKA'da her biri birden fazla değişken içeren iki veri kümesi (X: X1, X2, .. $\mathrm{Xp}$ ve $\mathrm{Y}: \mathrm{Y} 1, \mathrm{Y} 2, \ldots \mathrm{Yq}$ ) arasındaki ilişki, bu iki kümeden seçilen doğrusal bileşenler arasındaki korelasyonlar yardımıyla araştırılır (Tatlıdil, 1996).

KKA'nın amacı, değişken setleri arasındaki ilişkiyi maksimize edecek en uygun yapıyı veya boyutluluğu belirlemektir (Kalaycı, 2014; Hardle ve Simar, 2015). KKA birden fazla sayıdaki bağımsız değişkeni yine birden fazla bağımlı değişken kullanarak yordamak için kullanılır. Ancak, böyle bir ayrıma gerek kalmadan da değişken setleri arasındaki ilişkinin incelenmesi mümkündür (Sharma, 1996; Kalayc1, 2014).

KKA’nın iki temel araştırma sorusu: "Bağımlı ve bağımsız değişken setleri arasındaki anlamlı ilişkinin olup olmadı̆̆ ve eğer ilişki var ise her bir değişkenin bu ilişkideki payının araştırılmasıdır" (Bayyurt, 2004; Ho, 2014).

Bu araştırmada kanonik korelasyon analizi kullanılarak SSV, FSV, KYSV ve İSV değişkenlerinin ağırlıklı kombinasyonlarından oluşan stres puanları veri seti ile temel performans ve başarı performansı değişkenlerinin ağırlıklı kombinasyonlarından oluşan bireysel performans veri seti arasındaki ilişkinin ortaya konulması amaçlanmıştır. Bu durumda problem cümlesi "stres puanları ve bireysel performans değişken setleri arasında ne yönde bir ilişki vardır?” şeklinde yazılabilir. Sıfır ve alternatif hipotezler ise aşağıdaki gibidir:

$\mathbf{H}_{\mathbf{0}}$ : Otel çalışanlarının stres puanları ile bireysel performansları arasında istatistiksel olarak anlamlı bir ilişki yoktur.

$\mathbf{H}_{\mathbf{1}}$ : Otel çalışanlarının stres puanları ile bireysel performansları arasında istatistiksel olarak anlamlı bir ilişki vardır. 


\section{Bulgular}

KMO testi diğer bir ismiyle örnekleme yeterliliği istatiği, değişkenler arasındaki korelasyonları ve ifadelerin faktör analizine uygun olup olmadığını ve örneklem büyüklügünün uygunluğunu bize gösterir (Turanlı, Cengiz ve Bozkır, 2012, s. 47). Çünkü faktör analizi yapabilmenin ön şartı değişkenler arasında belli bir oranda korelasyon, ilişki bulunmasıdır. Bu ilişkilerin oranları ise aşağıda yer almaktadır:

- 0.80 ve yukarısı: Mükemmel

- $0.70-0.80$ arası: İyi

- $0.60-0.70$ arasi: Orta

- $0.50-0.60$ arası: Kötü

- $\quad 0.50$ 'den aşağısı: Kabul edilemez (Durmuş, Yurtkoru ve Çinko, 2013, s. 79-80).

Yukarıdaki açıklamalar ışığında KMO değeri 0-1 arası değişmektedir. KMO’nun 1 değerini alması değişkenlerin birbirlerini mükemmel bir şekilde, hatasız tahmin edebileceğini gösterir. KMO'nun en alt sınırı ise 0.50 'dir. Barlett küresellik testi ise $\mathrm{KMO}$ gibi değişkenler arasında yeterli oranda ilişki olup olmadığını gösterir. Eğer Barlett testinin p değeri 0.05 anlamlılık derecesinden düşük ise değişkenler arasında faktör analizi yapmaya yeterli düzeyde bir ilişki vardır. Eğer testin sonucu anlamlı değilse değişkenler faktör analizi yapmaya uygun değildir (Durmuş vd., 2013, s. 79-80).

Bu nedenle faktör analizinden önce yapılması gereken KMO analizinin sonuçları Tablo 1'de listelenmiştir.

Tablo 1. Stres Değerleme Ölçeğinin KMO ve Barlett Testleri

\begin{tabular}{l|l|l}
\hline Kaiser-Meyer-Olkin(KMO) & & $\mathbf{0 . 8 2 9}$ \\
\hline Barlett Küresellik Testi & Ki-kare değeri & 7054.123 \\
\hline & Anlamlılık(p değeri) & 0.000 \\
\hline
\end{tabular}

Tablo 1'de stres değerleme ölçeğine ilişkin yer alan barlett küresellik testinin p değeri 0.000 bulunmuş ve 0.05 anlamlılık derecesinden düşük olduğundan değişkenler arasında faktör analizi yapmaya yeterli düzeyde bir ilişki olduğu; KMO değerinin ise 0.829 olması ise 0.80 ve yukarısında olmasından dolayı örneklem büyüklügünün yeterli ve değişkenler arası ilişkinin mükemmel olduğu sonucunu göstermektedir.

Tablo 2. Bireysel Performans Ölçeğinin KMO ve Barlett Testleri

\begin{tabular}{l|l|l}
\hline Kaiser-Meyer-Olkin(KMO) & & $\mathbf{0 . 9 1 7}$ \\
\hline Barlett Küresellik Testi & Ki-kare değeri & 2934.695 \\
\hline & Anlamlılık(p değeri) & 0.000 \\
\hline
\end{tabular}

Tablo 2'de bireysel performans ölçeğine ilişkin yer alan barlett küresellik testinin p değeri 0.000 bulunmuş ve 0.05 anlamlılık derecesinden düşük olduğundan değişkenler arasında faktör analizi yapmaya yeterli düzeyde bir ilişki olduğu; KMO değerinin ise 0.918 olması ise 0.80 ve yukarısında olmasından dolayı değişkenler arası ilişki mükemmeldir. 
Verilerin faktör analizi için uygunluğuna karar verildikten sonra, faktör yük değerleri ve açıklanan varyans hesaplamalarına geçilmektedir. Faktör yük değeri, maddelerin faktörlerle olan ilişkisini açıklamada kullanılmaktadır. Yük değerinin en az 0.30 olması beklenmektedir. Eğer maddeler bu değerin altında ise elenmesi gerekmektedir. Faktör yüklerinin işaretine bakılmaksızın 0.60 ve üstü yük değerine sahip olan maddeler yüksek, 0.30-0.59 arası yük değeri ise orta düzeyde büyüklük olarak tanımlanmaktadır (Akdağ, 2011: 25).

Tablo 3. Stres Değerleme Ölçeğinin Faktör Ă̆ırlıkları

\begin{tabular}{|c|c|c|}
\hline Faktörler & $\begin{array}{l}\text { Faktör } \\
\text { Yükleri }\end{array}$ & $\begin{array}{l}\text { Açlklanan } \\
\text { Varyans }\end{array}$ \\
\hline Sosyal Stres Vericiler & & 17.824 \\
\hline 1.Yabancılarla karşılaştığımda rahatsız olurum. & .729 & \\
\hline 10. Sadece yaptığım iş yetersiz olduğunda hatırlanırım. & .756 & \\
\hline $\begin{array}{l}\text { 17.İşyerimdeki insanlarla veya ailemle olan sorunlarımı } \\
\text { çözümleyemem. }\end{array}$ & .409 & \\
\hline 19. Birlikte çalıştığım insanlardan çok az manevi destek alırım. & .784 & \\
\hline $\begin{array}{l}\text { 21. Fazla mesailer ve hafta sonunu da içine alan iş koşullarım } \\
\text { sebebiyle ailemin baskısını hissediyorum. }\end{array}$ & .513 & \\
\hline 23. Daha alt derecedeki kişilere olumsuz bir şey söylemem zor olur. & .738 & \\
\hline 24. Agresif kişilerle başa çıkmakta zorluk çekerim & .522 & \\
\hline 25. Pasif kişilerle çalışmakta güçlük çekerim. & .774 & \\
\hline $\begin{array}{l}\text { 27. Yaşıtlarım arasındaki bir çekişmede/tartışmada hakemlik } \\
\text { yapmaktan rahatsızlık duyarım. }\end{array}$ & .815 & \\
\hline $\begin{array}{l}\text { 28. Benden küçükler arasındaki tartışmada hakemlik yapmaktan } \\
\text { rahatsız olurum. }\end{array}$ & .727 & \\
\hline 29. Yaşıtlarımla tartışmaya girmekten kaçınırım. & .770 & \\
\hline 30. Amirlerimle tartışmaya girmekten kaçınırım. & .851 & \\
\hline 31. Astlarımla tartışmaya girmekten kaçınırım. & .871 & \\
\hline 36. Eşimin veya ailemin benden bir çok istekleri var. & .568 & \\
\hline 37. Ebeveynimin(anne, baba vb.) sağlığı ile ilgilenmem gerekiyor. & .764 & \\
\hline 38. Çocuklarımla veya ailemle iletişim kurmakta güçlük çekiyorum. & .517 & \\
\hline İşle İlgili Stres Vericiler & & 18.376 \\
\hline $\begin{array}{l}\text { 4. Birlikte çalıştığım insanlar yaptığım iş konusunda bilgi sahibi } \\
\text { değiller. }\end{array}$ & .349 & \\
\hline 5. Amirlerim ile görüş ayrılıklarım var. & .626 & \\
\hline 6.İş yerimde yaşanan çekişmelerle uğraşmak zamanımın çoğunu alır. & .636 & \\
\hline 7. “Yöneticilik” konusunda kendime güvenmiyorum. & .450 & \\
\hline $\begin{array}{l}\text { 8. Yöneticiler işimi yaparken yeni taleplerde bulunarak çalışmamı } \\
\text { engeller. }\end{array}$ & .631 & \\
\hline $\begin{array}{l}\text { 9. Çalıştığım bölüm ile diğer bölümler arasında çekişme/anlaşmazlık } \\
\text { var. }\end{array}$ & .435 & \\
\hline
\end{tabular}




\begin{tabular}{|c|c|c|}
\hline $\begin{array}{l}\text { 11. Beni etkileyecek olan kararlar veya değişiklikler, bilgim olmadan } \\
\text { veya bana sorulmadan yapılır. }\end{array}$ & .621 & \\
\hline $\begin{array}{l}\text { 15. Yakın olarak çalıștı̆ıı mesai arkadaşlarım, benden daha farklı } \\
\text { alanda eğitim almışlar. }\end{array}$ & .793 & \\
\hline 16. İşimi yapabilmem için, diğer departmanlara da gitmem gerekir. & .669 & \\
\hline 18. Diğer bölümlerle olan sorunlarımı çözümleyemem. & .391 & \\
\hline $\begin{array}{l}\text { 20. Bir plan üzerinde çalışmak yerine vaktimi onunla ilgili zorlukları } \\
\text { yenmek için harcıyorum. }\end{array}$ & .560 & \\
\hline 26. Birbirleri ile çakışan görevler beni güç durumda bırakır. & .493 & \\
\hline 32. Karmaşık işler canımı sıkar. & .534 & \\
\hline Kendini Yorumlama Biçiminden Kaynaklanan Stres Vericiler & & 17.869 \\
\hline 2. Bir grup önünde konuşurken tedirgin olurum. & .587 & \\
\hline 3. İstediklerimi yapıp yapmama konusunda tereddüt ederim. & .618 & \\
\hline 12. Yapacak çok işim, ancak çok az zamanım var. & .457 & \\
\hline 13. İşimde yaptıklarımdan daha yetenekli olduğumu düşünüyorum. & .394 & \\
\hline $\begin{array}{l}\text { 14. Şu anda yapmakta olduğum iş için yetersiz olduğumu } \\
\text { hissediyorum. }\end{array}$ & .732 & \\
\hline $\begin{array}{l}\text { 22. İşlerimi yetiştirebilmek için kendi kendime zaman sınırlarımı } \\
\text { koyarım. }\end{array}$ & .552 & \\
\hline 33. Kişisel ihtiyaçlarım, işyeri ile çatışma halindedir. & .705 & \\
\hline 35. Bir iş üzerinde dikkatimi toplamakta güçlük çekiyorum. & .470 & \\
\hline 39. Hissettiklerimi söylemekte güçlük çekiyorum. & .549 & \\
\hline Fiziki Çevreden Kaynaklanan Stres Vericiler & & 12.956 \\
\hline 34. Gürültülü çevrem beni rahatsız ediyor. & .578 & \\
\hline 40. Çalıştığım yerde çok sigara içiliyor. & .598 & \\
\hline 41.Çalıştığım yerdeki koku beni rahatsız ediyor. & .647 & \\
\hline 42.Oturduğum yerdeki çevre kirliliğinden şikayetçiyim. & .722 & \\
\hline 43.Oldukça gürültülü bir yerde çalışyorum. & .676 & \\
\hline Toplam Varyans Açılama Oranı (\%): 67.025 & & \\
\hline
\end{tabular}

Faktör yüklerine bakıldığında 25 tanesinin \%60'ın üzerinde; yüksek faktör değerine sahip; 18 tanesinin ise 0.30- 0.59 arasında orta düzeyde olduğu ve analizlere dahil edilebileceği belirlenmiştir. Analizler sonrasında da, stres nedenlerini belirlemeye yönelik yer alan 43 ifadenin diğer çalışmalara paralel olarak 4 boyutta toplandığı görülmüştür. Bunlar sosyal stres vericiler, işle ilgili stres vericiler, kendini yorumlama biçiminden kaynaklanan stres vericiler ve fiziksel çevreden kaynaklanan stres vericilerdir. Ancak, farklı olarak bazı ifadelerin $(1,5,17,42$ ve 43) iki boyut altında da yer alması faktör analizi için sıkıntı oluşturacağından ifadelerin faktör yükleri alındıktan sonra hangi boyuta daha yakınsa onun ifadesi olarak kabul edilmiştir. Buna göre; 42 ve 43 . ifadeler hem işle ilgili stres vericiler hem de çevreyle ilgili stres vericilerde iken 
çevresel stres vericiler boyutuna, 17. ifade hem işle ilgili stres vericiler hem de sosyal stres vericilerde iken sosyal stres vericiler boyutunun altına, 1 . ifade hem kendini yorumlama biçiminden kaynaklanan stres vericiler hem de sosyal stres vericilerde iken sosyal stres vericiler boyutunun altına ve 5. ifade hem sosyal stres vericiler hem de işle ilgili stres vericiler de iken işle ilgili stres vericiler boyutunun altına alınmıştır. Faktörlerin toplam varyansın \%67'sini açıllaması ise sosyal bilimler için faktör yapısının güçlü olduğunu göstermektedir.

Tablo 4. Bireysel Performans Ölçeğinin Faktör Ă̆grlıkları

\begin{tabular}{l|c|c}
\hline Faktörler & $\begin{array}{c}\text { Faktör } \\
\text { Yükleri }\end{array}$ & $\begin{array}{c}\text { Açılanan } \\
\text { Varyans }\end{array}$ \\
\hline Temel Performans & $\mathbf{3 2 . 2 7 6}$ \\
\hline 1.İ̧̧lerimi devamlı zamanında bitiririm. & .618 & .644 \\
2.Düzenli ve belirli bir amaç doğrultusunda çalışırım. & .771 & \\
3.Çok düşük idare ve teşvik seviyesinde bile çalışabilirim. & .634 & \\
4.Görev odaklı çalışırım. & & $\mathbf{3 7 . 6 6 3}$ \\
\hline Başarı Performansı & .695 & \\
\hline 5.İşimi yüksek çalışma temposunda sürdürürüm. & .746 & \\
6.İşimde büyük işler başarırım. & .781 & \\
7.Yüksek kaliteli işler ortaya koyarım. & .849 & \\
8.Çalışmalarım sürekli üst düzey sonuçlar verir. & .885 & \\
9.İşimde çok çalışkan ve hareketliyimdir. & & \\
\hline Topplam Varyans Açıklama Oranı (\%): 69.939 &
\end{tabular}

Faktör yüklerine bakıldığında hepsinin \%60’ın üzerinde; yüksek faktör değerine sahip olduğu ve analizlere dahil edilebileceği belirlenmiştir. Analizler sonrasında da, bireysel performansı ölçmeye yönelik yer alan 9 ifadenin literatüre uygun olarak 2 faktör altında toplandığ 1 görülmüştür. Bunlar temel performans ve başarı performansıdır. Faktörlerin toplam varyansın \%69'unu açıklaması ise sosyal bilimler için faktör yapısının güçlü olduğunu göstermektedir.

Tablo 5. Ölçeklerin Cronbach's Alpha Değerleri

\begin{tabular}{l|l}
\hline & Cronbach's Alpha \\
\hline Stres Değerleme Ölçeği Faktörleri & $\mathbf{0 . 9 1 1}$ \\
\hline Sosyal Stres Vericiler & 0.794 \\
İşle İlgili Stres Vericiler & 0.806 \\
Kendini Yorumlama Biçiminden Kaynaklanan Stres Vericiler & 0.685 \\
Fiziki Çevreden Kaynaklanan Stres Vericiler & 0.705 \\
\hline Bireysel Performans Ölçeği Faktörleri & $\mathbf{0 . 9 4 2}$ \\
\hline Temel Performans Boyutu & 0.856 \\
Başarı Performansı Boyutu & 0.943 \\
\hline
\end{tabular}


Kalaycı'ya göre (2006, s. 405), cronbach's alpha değerleri $0.60 \leq \alpha<0.80$ aralığında güvenilir ve $0.80 \leq a<1.00$ aralığında ise oldukça güvenilir olarak kabul edilmektedir. Bu oranlarda araştırmada kullanılan ölçeklerin oldukça güvenilir olduğunu göstermektedir.

Geçerlilik ve güvenilirlik bilgilerinden sonra analize geçildiğinde, kanonik korelasyon uygulaması için Antalya merkezdeki beş yıldızlı otel çalışanlarının stres puanları kullanılmıştır. Bunun için çalışanların sosyal, iş, kendini yorumlama biçimi ve fiziki çevreden kaynaklı oluşan stres puanları alınarak SSV, İSV, KYSV ve FSV değişkenleri ile "stres puanları" değişken seti oluşturulmuştur. İkinci değişken kümesi için ise çalışanların bireysel performanslarını ortaya koyan temel performans ve başarı performansı değişkenleri seçilerek "bireysel performans" değişken seti oluşturulmuştur. Uygulama kapsamında "stres puanları" değişken seti bağımsız değişken olarak, "bireysel performans” değişken seti ise bağımlı değişken olarak ele alınmıştır.

Kanonik korelasyon analizini gerçekleştirmek için kullanılacak model açılandıktan sonra kurulan kanonik modelin anlamlı olup olmadığına bakılmıştır. Bunun için Pilai's criterion, Hotelling's trace, Wilks' lambda ve Roy's GCR gibi testler kullanılabilmektedir. Ancak, genel olarak araştırmacılar tarafından daha kullanışlı olan Wilks' $\lambda$ tercih edilmiştir (Sherry ve Henson, 2005). Tablo 6'de bu testlere ait sonuçlar verilmiştir.

\section{Tablo 6. Çok Değişkenli Anlamlılık Testleri}

\begin{tabular}{l|l|l|l|l|l} 
Test Adı & Değer & Yaklaşık F & Hipotez & SD Hata & F'in Anlamlılık Değeri \\
\hline Pillais & .73463 & 50.21851 & 8.00 & 692.00 & .000 \\
\hline Hotellings & 2.52236 & 108.46148 & 8.00 & 688.00 & .000 \\
\hline Wilks & .27980 & 76.80431 & 8.00 & 690.00 & .000 \\
\hline Roys & .71443 & & & &
\end{tabular}

$\left(\mathrm{S}=2, \mathrm{M}=1 / 2, \mathrm{~N}=171 \frac{1}{2}\right)$

Tablo 6'daki bulgulara göre, oluşturulan kanonik model istatistiksel olarak anlamlıdır (Wilks' $\lambda=0.27980, \mathrm{~F}(8,690.00)=76.80431, \mathrm{p}<0.001)$. Dolayısıla stres puanları ve bireysel performans setleri arasında kayda değer bir ilişki olduğu söylenebilir. Ancak bu testlerin anlamlılığı elde edilen ilişkinin gücü hakkında bilgi vermemektedir. Bu nedenle, kanonik korelasyon analizinde modelin anlamlılığının yanı sıra ilişkinin büyüklügünü ölçmek için etki büyüklüğüne bakılmalıdır. Bu konuda da ters etki büyüklüğü olarak adlandırılan Wilks' $\lambda$ değerinden faydalanılmaktadır. Wilks $\lambda$ değeri, analiz sonucunda elde edilen modelde kanonik değişkenler arasında açıklanamayan varyansı ifade etmektedir. Dolayısıyla " $1-\lambda$ ” değeri kanonik değişkenlerin paylaştıkları ortak varyans miktarını göstermekte ve regresyon analizindeki $\mathrm{R}^{2}$ değeri gibi yorumlanabilmektedir. Buna göre etki büyüklüğü 1 - Wilks' $\lambda=1-0.27980=0.7202$ 
olarak hesaplanabilir. Buna göre, stres puanları ve bireysel performans setleri arasındaki paylaşılan ortak varyans $\% 72$ 'dir.

Kanonik korelasyon analizinde oluşturulabilecek maksimum kanonik değişken çifti sayısı, hangi değişken setinde daha az sayıda değişken varsa, o setteki değişken sayısına eşittir (Cohen, Cohen, West ve Aiken, 2003). Araştırmada iki veri setinden birinde 4, diğerinde 2 değişken bulunmaktadır. Dolayısıyla oluşturulabilecek maksimum kanonik değişken çifti sayısı 2'dir. Kurulan kanonik model anlamlı olmakla birlikte her bir kanonik fonksiyonunda anlamlılı̆̆ının test edilmesi gerekmektedir. Kanonik korelasyondan elde edilen kanonik modelin anlamlılığı test edilirken, kanonik fonksiyonların yığılmalı değerleriyle işlem yapılmaktadır. Bu nedenle, kanonik fonksiyonların yığılmalı değerlerinin istatistiksel olarak anlamlı olduğu bir kanonik modelde, kanonik fonksiyonların bir kısmı anlamlı iken bir kısmı için kanonik değişkenler arasındaki ilişki çok düşük olabilir ve bu ilişki istatistiksel olarak anlamlı bulunmayabilir. Dolayısıyla kanonik korelasyon analizi sonuçları yorumlanırken kanonik model ile birlikte her bir kanonik fonksiyonun anlamlılı̆̆ının ayrı ayrı değerlendirilmesi gerekmektedir. Kanonik fonksiyonların hangilerinin anlamlı olduğuna karar vermek için kanonik fonksiyonlara ilişkin öz değerler ve kanonik korelasyon değerleri incelenmektedir (Sherry ve Henson, 2005). Tablo 7'de model için geliştirilen 2 kanonik fonksiyon için özdeğerler ve kanonik korelasyonlar sunulmaktadır.

\begin{tabular}{|c|c|c|c|c|c|}
\hline Kök & Özdeğer & Yüzde & $\begin{array}{l}\text { Yığılmalı } \\
\text { Yüzde(Küm.yüzde) }\end{array}$ & Kanonik Kor. & $\begin{array}{l}\text { Kanonik } \\
\text { Kor.karesi }\end{array}$ \\
\hline 1 & 2.50175 & 99.18273 & 99.18273 & .84524 & .71443 \\
\hline 2 & .02061 & .81727 & 100.00000 & $\mid .14212$ & .02020 \\
\hline
\end{tabular}

Tablo 7 incelendiğinde birinci kanonik fonksiyona ait kanonik korelasyonun 0.84524 olduğu ve bu fonksiyonun stres puanları ve bireysel performans setleri arasındaki varyansın \% 71.443'ünü açıkladığı görülmektedir. İkinci kanonik fonksiyonun katkısı ise \%2.02'dir. Bu yüzden yalnızca birinci kanonik fonksiyonun önemli bir katkıda bulunduğu söylenebilir.

Buraya kadar elde edilen sonuçlara göre, modelin istatistiksel olarak anlamlı olduğu ve yüksek derecede kabul edilebilecek bir etki büyüklügüne sahip olduğu söylenebilir. Ayrıca, yalnız birinci kanonik fonksiyon istatistiksel olarak anlamlı ve iki değişken seti arasındaki varyansı en çok açıklayan birinci kanonik fonksiyon olduğundan, yalnızca birinci kanonik fonksiyon yorumlanabilir.

Kanonik korelasyon analizinde diğer bir aşama da, veri setlerinde yer alan değişkenlerin kanonik değişkenler arasındaki ilişkiye nasıl bir katkı sağladığı ile ilgilidir. Standartlaştırılmış kanonik katsayılar ve yapısal katsayılar değişkenlerin her birinin kanonik fonksiyonlara 
katkılarını vermektedir. Buna göre stres puanları değişkenlerinin birinci kanonik fonksiyona katkıları sırasıyla SSV' den alınan puanlar (1.028), ISSV' den alınan puanlar (0.0723), KYSV' den alınan puanlar (0.1393), FSV' den alınan puanlar (-.0819) şeklinde, bireysel performans değişkenlerinin birinci kanonik fonksiyona katkıları ise temel performans (.937), başarı performansı (.961) şeklindedir (Tablo 8). Standartlaştırılmış kanonik korelasyonların yorumlanması özellikle çoklu doğrusal bağlantı olması durumunda sağlıklı olmadığından, kanonik değişkenlerle her iki değişken setleri arasındaki korelasyon olarak verilen yapı katsayılarını yorumlamak daha yerinde olacaktır.

Tablo 8. Kanonik Fonksiyonlar İçin Kanonik Çözümleme

\begin{tabular}{l|l|l|l|l|l|l|l}
\hline \multicolumn{4}{c}{ 1.Kanonik fonksiyon } & \multicolumn{5}{c}{ 2.Kanonik fonksiyon } \\
\hline & $\begin{array}{l}\text { Std. } \\
\text { katsa } \\
\text { y1 }\end{array}$ & $\mathbf{R}_{\mathbf{c}}$ & $\mathbf{R}_{\mathbf{c}}^{2}(\%)$ & $\begin{array}{l}\text { Std. } \\
\text { katsayı }\end{array}$ & $\mathbf{R}_{\mathbf{c}}$ & $\mathbf{R}_{\mathbf{c}}^{2}(\%)$ & $\mathbf{H}^{2}(\%)$ \\
\hline SSV & 1.028 & $\mathbf{. 9 8 6}$ & 97.21 & -.037 & -.075 & 0.57 & $\mathbf{9 7 . 7 8}$ \\
\hline ISV & .0723 & -.018 & 0.03 & 1.434 & .595 & 35.47 & 35.5 \\
\hline KYSV & .1393 & -.105 & 1.10 & -.525 & .106 & 1.14 & 2.24 \\
\hline FSV & -.0819 & -.008 & 0.64 & -.823 & -.241 & 5.83 & 6.47 \\
\hline $\begin{array}{l}\text { Temel } \\
\text { per. }\end{array}$ & .937 & $\mathbf{. 9 3 7}$ & 87.91 & .347 & .347 & 12.08 & $\mathbf{9 9 . 9 9}$ \\
\hline $\begin{array}{l}\text { Başar1 } \\
\text { per. }\end{array}$ & .961 & $\mathbf{. 9 6 1}$ & 92.53 & -.273 & -.273 & 7.46 & $\mathbf{9 9 . 9 9}$ \\
\hline
\end{tabular}

Std katsayı= standartlaştııılmış kanonik katsayı, $\mathrm{R}_{\mathrm{c}}=$ yapı katsayısı, $\mathrm{R}_{\mathrm{c}}{ }^{2}=$ yapı katsayısının karesi, $\mathrm{H}^{2}=$ ortaklık katsayısı

Değişkenlerin bulundukları veri seti ile paylaştıkları varyansın önemli olup olmadığının tespitinde .45 değeri ölçüt olarak alınmaktadır. Buna göre, . 45 ve üzerindeki $\mathrm{R}_{c}$ ve $\mathrm{H}^{2}$ değerlerine sahip değişkenlerin bulundukları veri setine katkılarının önemli olduğu söylenebilir. Bu ölçüt faktör analizinde .45 ve üzerinde faktör yüküne sahip olan maddelerin oldukça iyi maddeler olarak kabul edilmesi yargısından yola çıkılarak belirlenmiştir (Sherry ve Henson, 2005). Tablo 8'deki bulgulara göre, birinci kanonik fonksiyonda SSV değişkeninin stres puanları veri setine olan katkılarının .45’in( $\mathrm{R}_{\mathrm{c}}$ değerleri) üzerinde; buna karşın FSV, KYSV ve İSV değişkenine ait yapısal katsayıların .45 değerinin altında olduğu belirlenmiştir. Buna göre, birinci kanonik fonksiyon için SSV değişkenlerinin stres puanları veri setine olan katkılarının FSV, KYSV ve İSV değişkenlerinin stres puanları veri setine olan katkısına göre daha önemli olduğu söylenebilir.

Yine Tablo 8'deki bulgulara göre, birinci kanonik fonksiyonda temel performans ve başarı performansı değişkenlerinin bireysel performans değerleme veri setine olan katkılarının .45'in üstünde olduğu bulunmuştur. Bu durumda, birinci kanonik fonksiyonda temel performans ve başarı performansı değişkenlerinin bireysel performans değerlendirme veri setine olan katkıları oldukça önemlidir. SSV değişkenine ait yapısal katsayıların anlamlı olduğu birinci kanonik fonksiyonda işareti pozitiftir. Birinci kanonik fonksiyonda bireysel performans değerlendirme 
veri setine ilişkin değişkenler incelendiğinde ise, temel performans ve başarı performansı değişkenlerinin işaretlerinin pozitif olduğu saptanmıştır. Buna göre temel performans ve başarı performansı aynı yönlü ilişki içerisindedir. Tablo 8'de ayrıca SSV değişkeni ile temel performans ve başarı performansı değişkenleri arasında pozitif bir ilişki bulunmaktadır. Bu bulgu, çalışanların sosyal stres vericilerden aldıkları puanlar (SSV) arttıkça temel performans ve başarı performanslarının da arttığını göstermektedir.

\section{Sonuç}

Otel sektöründeki insan kaynaklarının yönetimi; endüstrinin, müşterilere başarıyla hizmet etmesi için insan kaynağına yüksek oranda ihtiyaç duyması nedeniyle giderek önemli etkiler yaratmaktadır. Bu nedenle, stres türleri ve bireysel performans ilişkisinin araştırılması büyük önem taşımaktadır. Bu araştırmada, otel çalışanlarının streslerinin bireysel performanslarıyla ilişkisi Kanonik Korelasyonla araştırılmıştır. Ancak stres ve bireysel performans ilişkisi, Mayerson stres kaynağı ölçeği ve bireysel performans değerleme ölçeği envanterindeki maddeler ve maddelere verilen yanıtlarla sınırlı kalmıştır. Otel çalışanlarının bireysel performanslarına dair yönetici değerlendirmesinin alınamadığı, çalışanların bireysel performanslarını kendilerinin değerlendirmesi diğer bir kısıtı oluşturmuştur. Kısıtlar belirlendikten sonra, çalışmada kullanılan ölçeklerin geçerliliklerine, güvenilirliklerine ve kanonik korelasyonla kurulan modelin anlamlılığına bakılmıştır. Bunun için kullanılan Wilks' $\lambda$ testi sonucunda stres puanları ve bireysel performans setleri arasında anlamlı bir ilişki olduğu saptanmıştır. Analiz sonucunda, stres puanları ile bireysel performans değerlendirme veri setleri arasındaki ilişkiye ait iki kanonik fonksiyon elde edilmiştir ve yalnızca birinci kanonik fonksiyonun anlamlı olduğu görülmüştür. Stres puanları ve bireysel performans değerlendirme veri setleri arasındaki ilişkiyi maksimum yapacak şekilde hesaplanan birinci kanonik fonksiyonda veri setleri arasındaki korelasyon .84524 olarak hesaplanmıştır. Buna göre, ilk kanonik fonksiyonda stres puanları ile bireysel performans değerlendirme veri setlerinin \%71.44’lük bir varyans paylaştıkları ortaya çıkmıştır. Sonrasında yapılan kanonik çözümleme ile de ilişkilerin yönlerine bakılmıştır. Kanonik korelasyon analizinden elde edilen kanonik fonksiyonların yığılmalı değerlerinden oluşan kanonik modelde, stres puanları ve bireysel performans değerlendirme veri setlerinin paylaştıkları ortak varyans $\% 72$ olarak hesaplanmıştır.

Araştırma sonucunda stresin, sosyal stres vericilerden alınan puanlar, işle ilgili stres vericilerden alınan puanlar, kendini yorumlama biçiminden kaynaklanan stres vericilerden alınan puanlar ve fiziki çevreden kaynaklanan stres vericilerden alınan puanlar gibi 4 ana alanı arasında, sosyal stres vericilerden alınan puanlar boyutu haricindeki diğer boyutlarının bireysel performans ile yüksek bir ilişkiye sahip olmadığı belirlenmiştir. Sadece, sosyal stres vericilerden alınan puanlar ve bireysel performans arasında pozitif bir ilişki olduğu görülmüştür. Bu bulgu, otel çalışanlarının sosyal stres vericilerden aldıkları puan arttıkça bireysel performanslarının da artan şekilde tetiklendiğini göstermektedir. Bu durum istenen performansın sağlanması için gerekli bir durumdur(Yılmaz, 2012; Ergül, 2012; Yılmaz ve Ekici 2003). Çünkü, AbuAlRub(2004), iş stresi ile çalışanların performansı arasındaki ilişkinin U şeklinde bir eğri 
olduğunu göstermiştir. Buna göre, orta seviye de bir iş stresine sahip olan çalışanların iş performansı, yüksek ya da düşük stres seviyesine sahip olanlara oranla daha iyi olarak belirtilmektedir(Mansor ve Malekian, 2014). Palmer vd.(2004)'de stresli çalışanların sağlıksız, kötü motive olmuş ve verimsiz olma olasılıklarının düşük, işletmelerinin rekabetçi pazarda başarılı olma ihtimallerinin ise daha yüksek olduğunu vurgulamıştır. Yapılan farklı çalışmalarda da orta düzeyde stresin olması durumunda ortalama performans sergilendiği belirtilmiştir(Yadav ve Halyal, 1999; Imtiaz ve Ahmad, 2009; Juyal, 2011). Bazı araştırmacılar ise, çalışma sonuçlarından farklı olarak yüksek düzeydeki iş stresi ve örgütsel performans arasında güçlü bir korelasyon olduğunu göstermiştir(Wright, Bonett ve Sweeney, 1993; Daniels ve Harris, 2000).

İşin özellikleri (Chiang, Birtch ve Kwan, 2010), düşük karar verme yetkisi (Wilkie, 2001), belirsiz iş tanımları (Robbins, 2001), uzun çalışma saatleri (Seta, Paulus ve Baron, 2000) gibi nedenlerle otel çalışanlarının yaşadığı stres, sadece performanslarını değil, aynı zamanda müşteri memnuniyetini de (Li vd., 2012) etkileyebilmektedir. Müşteri hizmetleri alanındaki çalışanların zayıf iş performansı göstermesi (Beehr vd., 2000), servis aksaklıklarına sebep olarak otellerin imajını olumsuz yönde etkileyebilmektedir (Yoo, Shin ve Yang, 2006). Bu nedenle, otel çalışanlarının iş performansını etkileyen faktörlerin belirlenmesi, müşterilerin ihtiyaç ve beklentilerinin daha iyi karşılanması ve otel imajının korunabilmesi için çok önemlidir. Sektörün başarısının çalışanların bireysel performanslarına bağlı (Walker, 2007) olduğu düşünüldüğünde, stres seviyesinin azaltılması otel sektöründe uygulayıcılar ve araştırmacılar için büyük önem taşımaktadır (Chiang, Birtch, ve Kwan, 2010; Kim, Murrmann, ve Lee, 2009).

Stresin günden güne artan nedenleri, etkileri, tıbbi rahatsızlıkları ve sonuçların yüklediği ekonomik maliyetler düşünülürse, göz ardı edilmesi söz konusu değildir. İşletmelerin başarısı çalışanlarının başarısı ya da başarısızlığı ile doğru orantılı olarak ilerlemektedir. Bu nedenle işletmeler, çalışanların stres kaynaklarını doğru bir şekilde belirleyip, kontrol altına alınması için gerekli önlemleri uygulamak konusunda çalışmalıdırlar. Gerçekten de birçok işletme, meditasyon, kas gevşetici egzersiz (Johns, 1992), psikoterapi (Coffey, 1994) gibi stres yönetimi eğitim programlarıyla stresin olumsuz etkilerini hafifletmek ve (Brymer, Perrew ve Johns, 1991) çalışanların stresini yönetmek için önemli zaman ve çaba harcamaktadır. İşletmeler, bu çalışmaları etkin bir şekilde yaptıkları sürece, stresin olumsuz etkilerini yenip olumlu etkilerinden yararlanarak örgüt başarısını artırabilirler. Genel olarak stresten tümüyle kurtulabilmek mümkün olmasa da, en azından belli bir seviyenin altında tutulmaya çalışılmalıdır. Bu anlamda sosyal destek (Tutar, 2000), iş zenginleştirme (Tosi, Zakem ve Berger, 1990), rollerin netleştirilmesi (Özkalp ve Kırel, 2001) gibi stres yönetiminde kullanılacak stratejilerinde amacı çalışanları optimal stres seviyesinde tutabilmek olmalıdır. Bu çalışmada, performans içinde bir miktar stresin gerekli olduğunu göstermektedir. $\mathrm{Bu}$ nedenle, otel yöneticileri, bu çalışmanın sonuçlarına dayalı olarak stres yönetimi eğitim programları, sakinlik, yüksek motivasyon programları tasarlayarak, stresi optimum düzeyde tutmanın yollarını arayabilirler. 


\section{Kaynakça}

AbuAlRub, R.F. (2004). Job Stress, Job Performance and Social Support Among Hospital Nurses. Journal of Nursing Scholarship, 36(1), 73-78.

AbuAlRub, R.F. (2006). Replication and Examination of Research Data on Job Stress and Coworker Social Support with Internet and Traditional Samples. Journal of Nursing Scholarship, 38(2), 200-204.

Akdağ, M. (2011). SPSS'de istatistiksel analizler. Ders notları, Malatya. İnonu. edu. tr.(erişim tarihi, 18, 03, 2018).

Babin, B.J. ve Boles, J.S. (1998). Employee Behavior in a Service Environment: A Model and Test of Potential Differences Between Men and Women. Journal of Marketing, 62(2), 77 91.

Baltaş, A., Baltaş, Z. (1993). Stres ve Başa Çıkma Yolları. İstanbul: Remzi.

Bayyurt, N. (2004). İşletme Performansı Değerlendirmesinde Kanonik Korelasyon Analizi. (Yayımlanmamış doktora tezi). İstanbul Üniversitesi/Sosyal Bilimler Enstitüsü, İstanbul.

Beehr, T.A. ve Glazer, S. (2005). Organizational Role Stress. Barling, J., Kelloway, E.K. ve Frone, M.R. (Ed.), Handbook of Work Stress (s. 7-34). CA: Thousand Oaks.

Beehr, T.A., Jex, S.M., Stacy, B.A. ve Murray, M.A. (2000). Work Stressors and Coworker Support as Predictors of İndividual Strain and Job Performance. Journal of Organizational Behavior, 21(4), 391-403.

Bernhardt, A., Dresser, L. ve Hatton, E. (2003). The coffee pot wars: unions and firm restructuring in the hotel industry. Appelbaum, E., Bernhardt, A. ve Murnane, R. (Ed.), Low-Wage America: How Employers are Reshaping Opportunity in the Workplace (s.3376). New York: Russell Sage Foundation.

Bhagat, R.S., Krishnan, B., Nelson, T.A., Leonard, K.M., Ford, D.L.J. ve Billing, T.K. (2010). Organizational Stress, Psychological Strain, and Work Outcomes in Six National Contexts: a Closer Look at the Moderating İnfluences of Coping Styles and Decision Latitude. Cross-Cultural Management, 17(1), 10-29.

Braham, B.J. (1998). Managing Stress. New York: McGraw-Hill.

Brown, S.P. ve Peterson, R.A. (1994). The Effect of Effort on Sales Performance and Job Satisfaction. Journal of Marketing, 58(2), 70-80.

Brymer, R.A., Perrew, P.L. ve Johns, T.R. (1991). Managerial Job Stress In The Hotel İndustry. International Journal of Hospitality Management, 10(1), 47-58.

Campbell, J. P. (1990). Modeling the Performance Prediction Problem in Industrial and Organizational Psychology. Dunnette, M.D. ve Hough, L.M. (Ed.), Handbook of Industrial and Organizational Psychology (s. 687-732). Palo Alto: Consulting Psychologists Press

Campbell, J.P., McCloy, R.A., Oppler, S.H., ve Sager, C.E. (1993). A Theory of Performance. Schmitt, E. ve Borman, W.C. (Ed.), Personnel Selection in Organizations (s. 35-70). San Francisco: Jossey-Bass. 
Canpolat, Ö. (2006). Çalışanların Stres Düzeyini Etkileyen Faktörler ve İş Sağlı̆̆ı Hemşiresinin Stres İle Başetmede Etkililiği. (Yayımlanmamış yüksek lisans tezi). Kocaeli Üniversitesi/Sağlık Bilimleri Enstitüsü, Kocaeli.

Chen, M.C. ve Huang, Y.W. (2014). Factors Influencing the Quality of Life of Nurse Anesthetists and the Correlations among Work Stress, Job Satisfaction, and Quality of Life: Acase Study of Three Medical Centers in Southern Taiwan. World Journal of Medicine and Medical Science, 2(2), 1-17.

Chiang, F.F.T., Birtch, T.A. ve Kwan, H.K. (2010). The Moderating Roles Of Job Control And Work-Life Balance Practices On Employee Stress In The Hotel And Catering Industry. International Journal of Hospitality Management, 29(1), 25-32.

Chiang, F.T., Birtch, T.A. ve Kwan, H.K. (2010). The Moderating Roles of Job Control and Work-life Balance Practices on Employee Stress in the Hotel and Catering Industry. International Journal of Hospitality Management, 29(1), 25-32.

Cleveland, J. N., O'Neill, J. W., Himelright, J. L., Harrison, M. M., Crouter, A. C., ve Drago, R. (2007). Work and Family Issues in the Hospitality Industry: Perspectives of Entrants, Managers, and Spouses. Journal of Hospitality \& Tourism Research, 31(3), 275-298.

Coffey, A.J. (1994). Timing is Everything'; Graduate Accountants, Time and Organizational Commitment. Sociology, 28(4), 943-956.

Cohen, J., Cohen, P., West, S. G., ve Aiken, L. S. (2003). Applied Multiple Regression/Correlation Analysis for the Behavioral Sciences. London: Lawrence Erlbaum Associates.

Cooper, C. L., \& Marshall, J. (1976). Occupational Sources of Stress: A Review of the Literature Relating to Coronary Heart Disease and Mental Ill Health. Journal of occupational psychology, 49(1), 11-28.

Daniels, K. ve Harris, C. (2000). Work, Psychological Well-being and Performance. Occupational Medicine, 50(5), 304-309.

Durmuş, B., Yurtkoru, E.S. ve Çinko, M. (2013). Sosyal Bilimlerde SPSS’le Veri Analizi. İstanbul: Beta.

Ergül, A. (2012). Çalışma Yaşamında Stresin Bireysel Performans Üzerindeki Etkileri: Eğitim ve Sağlık Çalışanlarına Yönelik Bir Araştırma. (Yayımlanmamış yüksek lisans tezi). Balıkesir Üniversitesi/Sosyal Bilimler Enstitüsü, Balıkesir.

Erkuş, A. (2012). Psikolojide Ölçme ve Ölçek Geliştirme. Ankara: Pegem.

Faulkner, B. ve Patiar, A. (1997). Workplace İnduced Stress Among Operational Staff in The Hotel İndustry. International Journal of Hospitality Management, 16(1), 99-117.

Fox, M.L, Dwyer, D.J. ve Ganster, D.C. (1993). Effects of Stressful Job Demands and Control on Physiological and Attitudinal Outcomes in a Hospital Setting. Academy of Management Journal, 36(2), 289-318.

French, S.E., Lenton, R., Walter, V. ve Eyles, J. (2000). An Empirical Evaluation of an Expanded Nursing Stress Scale. Journal of Nursing Measurement, 8(2), 161-178. 
Gilboa, S., Shiram, A., Fried, Y. and Cooper, C. (2008). A Meta Analysis of Work Demand Stressors and Job Performance: Examining Main and Moderating Effects. Personnel Psychology, 61(2), 227-272.

Gilboa, S., Shirom, A., Fried, Y. ve Cooper, C. (2008). A Meta-analysis of Work Demand Stressors and Job Performance: Examining Main and Moderating Effects. Personnel Psychology, 61(2), 227-272.

Ho, R. (2014). Handbook of Univariate And Multivariate Data Analysis With IBM SPSS $\left(2^{\text {nd }}\right.$. ed. $)$. Boca Raton, FL: CRC Press.

Imtiaz, S. ve Ahmad, S. (2009). Impact of Stress on Employee Productivity, PErformance and Turnover; an Important Managerial Issue. International Review of Business Research Papers, 5(4), 468-477.

Jackson, S.E. ve Schuler, R.S. (1985). A Meta-Analysis and Conceptual Critique of Research on Role Ambiguity and Role Conflict in Work Settings. Organizational Behavior and Human Decision Processes, 3(1), 16-78.

Johns, M.W. (1992). Reliability and Factor Analysis of the Epworth Sleepiness Scale. Sleep, 15(4), 376-381.

Jung, H.S. ve Yoon, H.H. (2013). Is the Individual or the Organization the Cause of Hotel Employees' Stress? A Longitudinal Study on Differences in Role Stress Between Subjects. International Journal of Hospitality Management, 33(1), 494-499.

Juyal, S. (2011). Occupational Stress and Job Involvement among Managers. Global Journal of Management Science and Technology, 1.

Kahn, R.L. ve Byosiere, P. (1994). Stress in Organizations. Handbook of Industrial and Organizational Psychology, 3, 571-650.

Kalaycı, Ş. (2006). SPSS Uygulamalı Çok Değişkenli İstatistik Teknikleri, Ankara: Asil.

Kalaycı, Ş. (Ed) (2014). Spss Uygulamalı Çok Değişkenli İstatistik Teknikleri (6.Basım) Ankara: Asil.

Kanfer, R. (1990). Motivation Theory and Industrial and Organizational Psychology. Handbook of Industrial and Organizational Psychology, 1(2), 75-130.

Karasar, N. (2009). Bilimsel Araştırma Yöntemi. Ankara: Nobel.

Karatepe, O.M. ve Tizabi, L.Z. (2011). Work-Related Depression in the Hotel Industry: A Study in the United Arab Emirates. International Journal of Contemporary Hospitality Management, 23(5), 608-623

Kaya, L. (2008). Birden Fazla Değişken İçeren Setler Arasındaki İlişkinin Kanonik Korelasyon Analizi İle Belirlenmesi. (Yayımlanmamış yüksek lisans tezi). Harran Üniversitesi/Fen Bilimleri Enstitüsü, Şanlıurfa.

Khan, D., Amjad, S. ve Kazmi, R. (2008). Occupational Stress and its Effect on Job Performance. A Case Study of Medical House Officers of District Abbottabad. Journal of Ayub Medical College Abbottabad, 20(3), 135-139 
Kim, B.P., Murrmann, S.K. ve Lee, G. (2009). Moderating Effects of Gender and Organizational Level Between Role Stress and Job Satisfaction among Hotel Employees. International Journal of Hospitality Management, 28(4), 612-619.

Kim, H.J. (2008). Hotel Service Providers' Emotional Labor: The Antecedents and Effects on Burnout. International Journal of Hospitality Management, 27, 151-161.

Kim, H.J., Shin, K.H. ve Umbreit, W.T. (2007). Hotel Job Burnout: The Role of Personality Characteristics. International Journal of Hospitality Management, 26(2), 421-434.

Kim, H.J., Shin, K.H. ve Umbreit, W.T. (2007). Hotel Job Burnout: The Role of Personality Characteristics. International Journal of Hospitality Management, 26(2), 421-434.

Kültür ve Turizm Bakanlığı Yatırım ve İşletmeler Genel Müdürlüğü, http://www.ktbyatirimisletmeler.gov.tr/TR,9579/turizm-tesisleri.html. (erişim tarihi: 27. 5. 2016).

Lambert, V. ve Lambert, C. (2001). Literature Review of Role Stress/strain on Nurses: An International Perspective. Nursing and Health Science, 3(1), 161-172.

Lepine, J.A., Lepine, M.A. ve Jackson, C.L. (2004). Challenge and Hindrance Stress: Living with Exhaustion, Motivation to Learn, and Learning Performance. Journal of Applied Psychology, 89(5), 883-895.

Lepine, J.A., Podsakoff, N.P. ve Lepine, M.A. (2005). A Meta-analytic Test of the Challenge Stressor-hindrance Stressor Framework: An Explanation for Inconsistent Relationships Among Stressors and Performance, Academy of Management Journal, 48(5), 764-775.

Levi, L. (1981). Preventing work stress. Reading, MA: Addison-Wesley.

Li, X., Sanders, K. ve Frenkel, S. (2012). How Leader-Member Exchange, Work Engagement and HRM Consistency Explain Chinese Luxury Hotel Employees' Job Performance. International Journal of Hospitality Management, 31(4), 1059-1066.

Malta, M. (2004). Stress at Work, A Concept in Stress Human Factors Limited. Business Psychology Strategy Development, 33, 125-133.

Mansor, S.M.S.S., Malekian, K.A. (2014). Correlation Between Psychological Stressors With Job PErformance Among Government Employess. 1 International Education Postgraduate Seminar, 2, 87-102, Malaysia.

Maslach, C. (2003). Job Burnout: New Directions in Research and Intervention. Current Directions in Psychological Science, 12(5), 189-192.

Mohr, A.T. ve Puck, J.F. (2007). Role Conflict, General Manager Job Satisfaction and Stress and the Performance of IJVs. European Management Journal, 25(1), 25-35.

Motowidlo, S.J., Borman, W.C., ve Schmit, M.J. (1997). A Theory of Individual Differences in Task and Contextual Performance. Human Performance, 10, 71-83.

Özkalp, E. ve Kırel, Ç. (2001). Örgütsel davranış. Eskişehir: Anadolu Üniversitesi Eğitim, Sağlık ve Bilimsel Araştırma Çalışmaları Vakfı Yayını 
Özpehlivan, M. (2015). Kültürel Farklılıkların İşletmelerde Örgüt İçi İletişim, İş Tatmini, Bireysel Performans ve Örgütsel Bağlllık Kavramları Arasındaki İlişkiye Etkileri: Türkiye-Rusya Örneği. (Yayımlanmamış doktora tezi). Okan Üniversitesi/Sosyal Bilimler Enstitüsü, İstanbul.

Palmer, S., Cooper, C., ve Thomas, K. (2004). A model of Work Stress. Counselling at Work. Winter, 5, 25

Papadopoulou-Bayliss, A., Ineson, E.M. ve Wilkie, D. (2001). Control and Role Conflict in Food Service Providers, International Journal of Hospitality Management, 20(2), 187-199.

Parker, D.F., ve DeCotiis, T.A. (1983). Organizational Determinants of Job Stress. Organizational Behavior and Human Performance, 32(2), 160-177.

Rigopoulou, I., Theodosiou, M., Katsikea, E. ve Perdikis, N. (2012). Information Control, Role Perceptions and Work Outcomes of Boundary Spanning Frontline Managers. Journal of Business Research, 65(5), 626-633

Robbins, S.P. (2001). Organizational Behavior. NJ: Prentice-Hall.

Roe, R.A. (1999). Work Performance: A Multiple Regulation Perspective. Cooper, C.L.ve Robertson, I.T. (Ed..), International Review of Industrial and Organizational Psychology (s. 231-335). Chichester: Wiley.

Ross, G.F. (1995). Work Stress and Personality Measures Among Hospitality Industry Employees. International Journal of Contemporary Hospitality Management, 7(6), 9-13.

Ross, G.F. (1997). Career Stress Responses Among Hospitality Employees. Annals of Tourism Research, 24(1), 41-51.

Samartha, V., Lokesh, M. ve Karkera, A. (2010). Impact of Occupational Stress on Employee Performance In Banks-An Empirical Study. Paradigm, 14(1).

Schepers, J.M. (2005). The Construction And Evaluation of A Generic Work Performance Questionnaire Fr Use with Administrative and Operational Staff. SA Tydskrif Vir Bedrysielunde, 34(1), 10-22.

Seta, C., Paulus, P. ve Baron, R. (2000). Effective Human Resource Relations: A Guide to People at Work. Boston: Allyn and Bacon.

Sharma, S. (1996). Applied Multivariate Techniquis. Canada: John Wilwy \& Sons.

Sherry, A. ve Henson, R.K. (2005). Conducting And İnterpreting Canonical Correlation Analysis In Personality Research: A User-Friendly Primer. Journal of Personality Assessment, 84(1), 37-48.

Singh, A.P. ve Dubey, A.K. (2011). Role of Stress and Locus of Control in Job Satisfaction among Middle Managers. The IUP Journal of Organizational Behavior, 10(1), 42-56.

Tabachnick, B.G. ve Fidell, L.S. (2001). Using Multivariate Statistics. Boston: Ally and Bacon.

Tabachnick, B.G. ve Fidell, L.S. (2006). Using Multivariate Statistics (5th Ed.). Boston:Pearson Education.

Tatlıdil, H. (1996). Uygulamalı Çok Değişkenli İstatistiksel Analiz. Ankara: Cem Web Obset. 
Thomas, J.C. ve Herson, M. (2002). Handbook of Mental Health in the Workplace. Thousand Oaks: Sage.

Tosi, M.F., Zakem, H., ve Berger, M. (1990). Neutrophil Elastase Cleaves C3bi on Opsonized Pseudomonas as well as CR1 on Neutrophils to Create a Functionally Important Opsonin Receptor Mismatch. The Journal of clinical investigation, 86(1), 300-308.

Turanlı, M., Cengiz, D.T. ve Bozkır, Ö. (2012). Faktör Analizi ile Üniversiteye Giriş Sınavlarındaki Başarı Durumuna Göre İllerin Sıralanması. İstanbul Üniversitesi İktisat Fakültesi Ekonometri ve İstatistik Dergisi, 17, 45-68.

Tutar, H. (2000). Kriz ve Stres Ortamında Yönetim. Hayat.

Van Dam, K. (2005). Employee Attitudes Toward Job Changes: An Application and Extension of Rusbult and Farrell's Investment Model. Journal of Occupational and Organizational Psychology, 78(2), 253-272.

Van Scotter, J., Motowidlo, S. J. ve Cross, T.C. (2000). Effects of Task Performance and Contextual Performance on Systemic Rewards. Journal of Applied Psychology, 85, 526535 .

Vandenberghe, C., Panaccio, A., Bentein, K., Mignonac, K. ve Roussel, P. (2011). Assessing Longitudinal Change of and Dynamic Relationships among Role Stressors, Job Attitudes, Turnover Intention, and Well Being in Neophyte Newcomers. Journal of Organizational Behavior, 32(4), 652-671.

Varca, P.E. (1999). Work Stress and Customer Service Delivery. The Journal of Services Marketing, 13(3), 229-239.

Viswesvaran, C. (1993). Modeling Job Performance: Is There A General Factor?. (Doctoral Dissertation). University of Lowa/ IA, Lowa City.

Walker, J.R. (2007). Introduction to Hospitality Management. Upper Saddle River, NJ: PrenticeHall.

Widmer, C. (1993). Role Conflict, Role Ambiguity, and Role Overload on Boards of Directors of Nonprofit Human Service Organizations. Nonprofit and Voluntary Sector Quarterly, 22(4), 339-356.

Wildes, V.J. (2007). Attracting and Retaining Food Servers: How İnternal Service Quality Moderates Occupational Stigma. International Journal of Hospitality Management, 26(1), 4-19.

Wright, T.A, Bonett, D.G. ve Sweeney, D.A. (1993). Mental Health and Work Performance: Results of a Longitudinal Field Study. Journal of Occupational and Organizational Psychology, 66(4), 277-284.

Yadav, V. ve Halyal, P. (1999). Job Involvement and Family Involvement as Determinants of Job Satisfaction and Marital Satisfaction. J. Community Guidance and Res, 16(3), 291-304.

Yılmaz, A. ve Ekici, S. (2003). Örgütsel Yaşamda Stresin Kamu Çalışanlarının Performansına Etkileri Üzerine Bir Araştırma. Yönetim ve Ekonomi, 10(2), 1-19. 
Yılmaz, V. (2012). Stresin Bireysel Performans Üzerindeki Etkileri. (Yayımlanmamış yüksek lisans tezi). Ufuk Üniversitesi/Sosyal Bilimler Enstitüsü, İstanbul.

Yoo, J., Shin, S.Y. ve Yang, I. (2006). Key Attributes Of İnternal Service Recovery Strategies As Perceived By Frontline Food Service Employees. International Journal Of Hospitality Management, 25(3), 496-509.

Zohar, D. (1994). Analysis of Job Stress Profile in the Hotel Industry. International Journal of Hospitality Management, 13(3), 219-231. 